\title{
Journal of Biodiversity \& Endangered Species
}

\section{Study of Bird Diversity in Gorakhpur University Campus}

Richa Singh, Avantika Jaiswal, Janhavi Singh, Nidhi Singh, Shailendra Kumar Bhaskar, Navneet Kumar, Singh VK and Singh DK *

Department of zoology, Environmental science, D.D.U. Gorakhpur University, Gorakhpur, U.P. 273009, India

*Corresponding author: Singh DK, Department of zoology, Environmental Science, D.D.U. Gorakhpur University, Gorakhpur, UP, India, Tel: +3334578305; E-mail: dksingh.gpu@yahoo.co.in

Received date: April 18, 2018; Accepted date: July 19, 2018; Published date: July 30, 2018

Copyright: $\odot 2018$ Singh R, et al. This is an open access article distributed under the terms of the Creative Commons Attribution License, which permits unrestricted use, distribution, and reproduction in any medium, provided the original author and source are credited.

\begin{abstract}
Study on bird diversity in the campus of Deen Dayal Upadhyaya Gorakhpur University, Gorakhpur was done, over a period of six months from September 2017 to February 2018. A total number of 45 bird species belonging to 23 families were recorded during the study covering an area of about $1.214 \mathrm{~km} 2$. University campus is $0.02 \%$ of total Gorakhpur area, and has $12.5 \%$ of the total bird species reported in Gorakhpur region. The study was divided into different regions that are: Botanical garden, Arts faculty, Law department, Helipad region, Pant bhawan. Of the 45 bird species observed, 4 were migratory namely Yellow-footed green pigeon, Rosy-starling, Robin accentor, Ashy drongo. The common bird species were Jungle babbler, common myna, spotted dove, blue rock pigeon, house crow, black drongo etc. The University campus has wide variety of trees, which may be one of the major contributing factor for the richness of bird species.
\end{abstract}

Keywords: Jungle babbler; Common myna; Spotted dove; Blue rock pigeon; House crow

\section{Introduction}

Birds are chordate belonging to class Aves. Aves is the Latin name for birds-feathered winged, bipedal, warm-blooded, egg laying vertebrate animal. They inhabit all the ecosystem across the globe. There has been a wide range in size of birds that is from Bee humming $5 \mathrm{~cm}$ to Ostrich $2.5 \mathrm{~m}$. Birds are some of the most prominent species of the Earth's biodiversity and being sensitive to environmental changes [1]. They act as a key indicator for assessing the status of ecosystem health. They are integral part of food chain and food web. Birds play a vital role in keeping balance of nature. They also help in pollination of flowers and dispersal of seeds. Richness, abundance and community composition of birds are often used by ecologists to understand the diversity of species in natural occurrence [2].

The major factor affecting the bird diversity is habitat destruction. Therefore, the majority of avian species are unknowingly enters to inhabit the urban area. The change in vegetation composition could impact the quantity and quality of habitat for birds in terms of food, water and cover, which can further affect diversity, abundance and distribution of birds $[3,4]$.

According to new research led by American Museum of Natural History suggest that there are about 18,000 bird species in the world [5]. A check-list of bird of India authored by Praveen et al., published by the journal Indian Bird 2016, there are about 1,263 species of bird present in India, which $12 \%$ of total bird species in the world [6-8]. According to Forest and Wildlife Department, Government of Uttar Pradesh, there are about 550 bird species in U.P. As per Avibase bird count (2013), there are about 358 species of bird found in Gorakhpur region [9-10].

This study aims to investigate the bird diversity in the university campus as no work on bird diversity was carried out in Deen Dayal Upadhyaya, Gorakhpur University, Gorakhpur campus. The proposal will be helpful in preparing a baseline data on bird diversity. The study will assess the difference in avian community among these areas $[11,12]$.

\section{Materials and Methods}

\section{Site selection}

The study was done in the Deen Dayal Upadhyaya Gorakhpur University campus which is confined within the area of $1.214 \mathrm{~km} 2$ and it is quite hostile for birds. The Ramghar Tal is approximately $4.2 \mathrm{~km}$ away from the University, so variety of birds can be easily seen. The university campus consist of more than 2,500 trees which provide wide range of habitats for the birds. Also, some of areas within in the university is quite silent which indirectly promote the bird diversity.

\section{Instrument used}

The instrument used was Olympus $8 \times 40$ DPS Binoculars. Binocular are field glasses are two telescopes mounted side-by-side and aligned to point in same direction. The most importance criterion is comport. The must be comfortable to hold. All binoculars have a set of two figures, indicating their specification, sometime followed by letter code as B or GA. The first figures refers to magnification, which is generally between $7 \mathrm{X}$ and $10 \mathrm{X}$. The second figures refers to diameter of larger lens, the objective lens, in $\mathrm{mm}$. The size of binocular is govern by this second figure GA or RA shows that the binocular is rubber covered, offering some protection against knock and wear. For general bird watching lower magnification $7 \mathrm{X}$ or $8 \mathrm{X}$ are used. The lower the magnification the brighter the image, the wider the field view.

\section{Area search}

The area search is a quantitative, habitats specific survey method that is widely applicable in most habitats, which is useful for diversity measurement such as species richness, bird community composition and relative abundance; as well as providing simple avian-habitat 
Page 2 of 3

relationship, natural history and reproductive information. The method is also well suited for public education and training observer. The method involves a time-constrained survey of a defined area, during which the observer records all birds seen or heard, differentiating those detected inside, outside, and flying over the search area. Vegetation surveys, using a relevant method, are conducted in a search area. The birds were observed by sitting and standing from a hiding places.

\section{Bird watching technique}

Identifying a bird can be a challenging process. Birds are active, energetic animals. Quick eye spotting is required in order to get possible detail in short span of time. The following techniques were used during bird watching-

Birds were recognised by fixing eye on them. Continuous observations were made regarding their movement, songs, feeding habit and size. Simultaneously specific calls and songs were also identified. General size, shape, distinctive strips and patches of colour including crown strips, eye lines, nape colour, eye arcs or rings and birds bill size were noted. Wing bars, colour patches, and marking on bird body during stationary stage or flying stage were noted. Leg colour and length were also noted in each observation. Observations was confirmed with the help of Avibase bird count (2013).

\section{Results and Discussion}

After our continuous observation of 181 days that is from September 2017 to February 2018, we have identifies 45 bird species which are listed below in Table 1:

\begin{tabular}{|c|c|c|}
\hline S.No. & Birds & Status in University \\
\hline 1. & House Sparrow & Widespread \\
\hline 2. & Jungle Babbler & Widespread \\
\hline 3. & Common Myna & Widespread \\
\hline 4. & Jungle Myna & Seasonal \\
\hline 5. & Asian Pied Starling & Seasonal \\
\hline 6. & Rosy Starling & Migratory \\
\hline 7. & Common Tailorbird & Rare \\
\hline 8. & Great Tit & Seasonal \\
\hline 9. & House Crow & Widespread \\
\hline 10. & Jungle Crow & Widespread \\
\hline 11. & RufousTreepie & Widespread \\
\hline 12. & Black Drongo & Widespread \\
\hline 13. & Racket Tailed Drongo & Widespread \\
\hline 14. & Ashy Drongo & Seasonal \\
\hline 15. & Red Whiskered Bulbul & Widespread \\
\hline 16. & Red Vented Bulbul & Widespread \\
\hline 17. & Purple Sunbird-FEMALE & Seasonal \\
\hline 18. & Indian Golden Oriole & Seasonal \\
\hline
\end{tabular}

\begin{tabular}{|c|c|c|}
\hline 19. & Indian Robin-FEMALE & Widespread \\
\hline 20. & Oriental Magpie Robin & Seasonal \\
\hline 21. & Taiga Flycatcher & Rare \\
\hline 22. & Robin Accentor & Migratory \\
\hline 23. & White-browed Wagtail & Seasonal \\
\hline 24. & Long-billed Pipit & Rare \\
\hline 25. & Hoopoe & Rare \\
\hline 26. & Blue Rock Pigeon & Widespread \\
\hline 27. & Spotted Dove & Widespread \\
\hline 28. & Yellow-footed Green Pigeon & Migratory \\
\hline 29. & Rose-ringed Parakeet & Rare \\
\hline 30. & Black Kite & Widespread \\
\hline 31. & Shikra & Rare \\
\hline 32. & Marsh Harrier & Rare \\
\hline 33. & Brown-headed Barbet & Seasonal \\
\hline 34. & $\begin{array}{ll}\text { Lesser } & \text { Himalayan } \\
\text { Flameback } & \end{array}$ & Rare \\
\hline 35. & $\begin{array}{l}\text { Lesser Golden-backed } \\
\text { Woodpecker }\end{array}$ & Rare \\
\hline 36. & $\begin{array}{l}\text { Greater } \quad \text { Spotted } \\
\text { Woodpecker }\end{array}$ & Rare \\
\hline 37. & Asian Koel-MALE & Rare \\
\hline 38. & Asian Koel-FEMALE & Rare \\
\hline 39. & Greater Coucal & Rare \\
\hline 40. & Common Hawk Cuckoo & Rare \\
\hline 41. & Spotted Owlet & Widespread \\
\hline 42. & Jungle Owlet & Rare \\
\hline 43. & Red-wattled Lapwing & Widespread \\
\hline 44. & Indian Hornbill & Rare \\
\hline 45. & Indian Roller & Rare \\
\hline
\end{tabular}

Table 1: Most frequently found birds.

The most frequently found birds are: House Sparrow, Jungle Babbler, Common Myna, Blue Rock Pigeon, Spotted Dove, Black Drongo, Racket-Tailed Drongo, RufousTreepie, Black Kite, and Bulbul. There are also some birds which were rarely sighted during the study period such as- Hoopoe, Indian Grey Hornbill, Woodpecker, Marsh Harrier, Shikra, Papiha, Indian Golden Oriole, Indian Roller etc. Also there were some migratory birds such as Yellow-Footed Green Pigeon, Rosy Starling etc (Figure 1). 


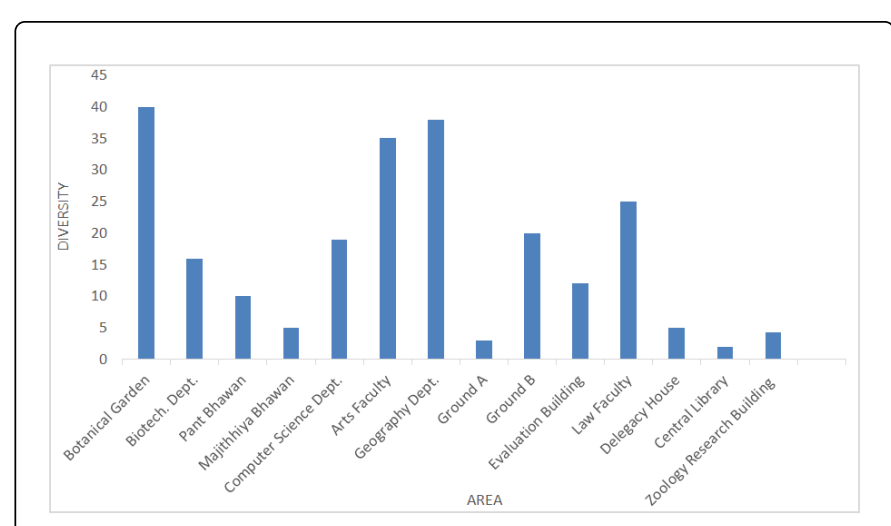

Figure 1: The Graph representing area wise bird diversity in university campus.

The species diversity and status of each bird species in different habitat were different as the habitat and vegetation cover is also different. The university campus is quite hostile for the birds. Botanical garden which is a silence zone, hence free form all kind of disturbance and also has wide range of trees such as- Eucalyptus, Banyan, Peeple, Sagaun, Ashok, Cycas, Bamboo, Neem etc. These trees provide habitat for different species of birds. The maximum number of birds were observed in botanical garden and arts faculty followed by law faculty, helipad region, computer science department. This may be due to large variety of plants which provide shelter as well as food and safety for birds.

\section{Conclusion}

Comparative data cleary indicate that campus has recorded highest diversity in botanical garden area and lowest diversity in zoology research buiding as compare to other selected areas of the university campus, this study help to notice a positive relationship between healthy ecosystem to bird recorded.

\section{References}

1. Main streaming conservation of migratory soaring birds in key productive sector along the rift valley/red sea flyway, bird identification manual, ministry of environment.

2. Joshi PP (2001) Assessment of Avian Population in different habitat around Amolakchand Mahavidyalaya Campus, Yavatmal, Maharashtra, India. J Biosci 4: 11.

3. Aggrawal A, Tiwari G, Harsh SA (1998) Diversity and Density Estimation of Birds of the Indian Institute of Forest Management Campus, Bhopal, India. J ThreatTax 7: 2-12.

4. Abdar MR (2013) Diversity and Richness of bird species in newly formed habitats of Chandoli National Park in Western Ghats, Maharastra State, India. Biodiv J 4: 235-242.

5. Bird checklist: Gorakhpur-Avibase- The World Bird Database.

6. Salim Ali (1984) The Book of Indian Birds, 11th edn.

7. Salim Ali (1996) The Book of Indian Birds, 12th edn.

8. Salim Ali (1996) The pictorial guide to the birds of Indian Subcontinent.

9. Khan, MMH (2008) Protected Areas of Bangladesh-A Guide to Wildlife. Nishorgo Program, Bangladesh Forest Department, Dhaka, Bangladesh pp: 304.

10. Mohsanin S, Khan MMH (2009) Status and seasonal occurrence of the birds in Jahangirnagar University Campus. Ban J Life Sci 21: 29-37.

11. Reza AMS, Hasan MA, Hossain M, Parween S (2012) Annotated checklist of birds of Rajshahi University Campus: an update. Univ J Zool, Rajshahi University 31: 39-47.

12. Asad R (2011) Rahamsni director. Bombay Natural History Society: bird diversity lecture- ENVIS Center on Avian Ecology.

This article was originally published in a special issue, entitled: "Researh \&

Reviews on Endangered Species", Edited by Michael O'Neal Campbell 